\title{
Influence of HLA-C environment on the spontaneous clearance of hepatitis C in European HIV-HCV co-infected individuals
}

\author{
Nolwenn Legrand ${ }^{1}$, Gaëlle David ${ }^{2}$, Audrey Rodallec ${ }^{3}$, Aurélie Gaultier ${ }^{3}$, Dominique \\ Salmon $^{4}$, Anne Cesbron ${ }^{1}$, Linda Wittkop ${ }^{5}$, François Raffi ${ }^{3}$, Ketevan Gendzekhadze ${ }^{6}$, \\ Christelle Retiere $^{7}$, Clotilde Allavena ${ }^{3}$, and Katia Gagne ${ }^{1}$ \\ ${ }^{1} \mathrm{EFS}$ \\ ${ }^{2}$ Etablissement Français du Sang \\ ${ }^{3} \mathrm{CHU}$ Hotel Dieu \\ ${ }^{4} \mathrm{APHP}$ \\ ${ }^{5} \mathrm{CHU}$ \\ ${ }^{6}$ City of Hope medican center \\ ${ }^{7}$ Etablissement Fraçais du Sang
}

August 5, 2020

\begin{abstract}
Natural Killer (NK) cell functions are regulated by diverse inhibitory and activating receptors including Killer cell Immunoglobulinlike receptors (KIR) which interact with HLA class I molecules. Some KIR/HLA genetic combinations were reported associated with spontaneous clearance (SC) of hepatitis $\mathrm{C}$ virus (HCV) but with discordant results, possibly reflecting KIR and/or HLA gene polymorphism according to populations. KIR/HLA genetic combinations associated with both an exhaustive NK and T cell repertoire were investigated in a cohort of HIV-HCV co-infected individuals with either SC (n=68) or chronic infection (CI, $\mathrm{n}=163$ ) compared to uninfected blood donors (Ctrl, $\mathrm{n}=100)$. Multivariate analysis showed that the HLA C2C2 environment was associated with SC only in European HIV-HCV co-infected individuals ( $\mathrm{OR}=4.30[1.57-12.25]$, p=0.005). KIR2D+ NK cell repertoire and potential of degranulation of KIR2DL1/S1+ NK cells were similar in SC European cohort compared to uninfected individuals. In contrast, decreased frequencies of KIR2DS1+ and KIR2DL2+ NK cells were detected in CI group of Europeans compared to SC and a decreased frequency of KIR2DL1/S1+ NK cells compared to controls. On the T cell side, higher frequencies of DNAM-1+ and CD57+ T cells were observed in SC in comparison to controls. Interestingly, SC subjects emphasized increased frequencies of KIR2DL2/L3/S2+ T cells compared to CI subjects. Our study underlines that the C2 environment may activate efficient KIR2DL1+ NK cells in viral context and maintain KIR2DL2/L3/S2+ mature T cell response in the absence of KIR2DL2 engagement with its cognate ligands in SC group of HCV-HIV co-infected European patients.
\end{abstract}

\section{Hosted file}

Manuscript Legrand et al. 08.05.2020.doc available at https://authorea.com/users/348965/ articles/474135-influence-of-hla-c-environment-on-the-spontaneous-clearance-ofhepatitis-c-in-european-hiv-hcv-co-infected-individuals

\section{Hosted file}

Table 1 Legrand et al. 08.05.2020.xlsx available at https://authorea.com/users/348965/ articles/474135-influence-of-hla-c-environment-on-the-spontaneous-clearance-ofhepatitis-c-in-european-hiv-hcv-co-infected-individuals 


\section{Hosted file}

Table 2 Legrand et al. 08.05.2020.xlsx available at https://authorea.com/users/348965/ articles/474135-influence-of-hla-c-environment-on-the-spontaneous-clearance-ofhepatitis-c-in-european-hiv-hcv-co-infected-individuals

\section{Hosted file}

Table 3 Legrand et al. 08.05.2020.xlsx available at https://authorea.com/users/348965/ articles/474135-influence-of-hla-c-environment-on-the-spontaneous-clearance-ofhepatitis-c-in-european-hiv-hcv-co-infected-individuals

\section{Hosted file}

Fig 1 Legrand et al. 08.05.2020.pptx available at https://authorea.com/users/348965/articles/ 474135-influence-of-hla-c-environment-on-the-spontaneous-clearance-of-hepatitis-c-ineuropean-hiv-hcv-co-infected-individuals

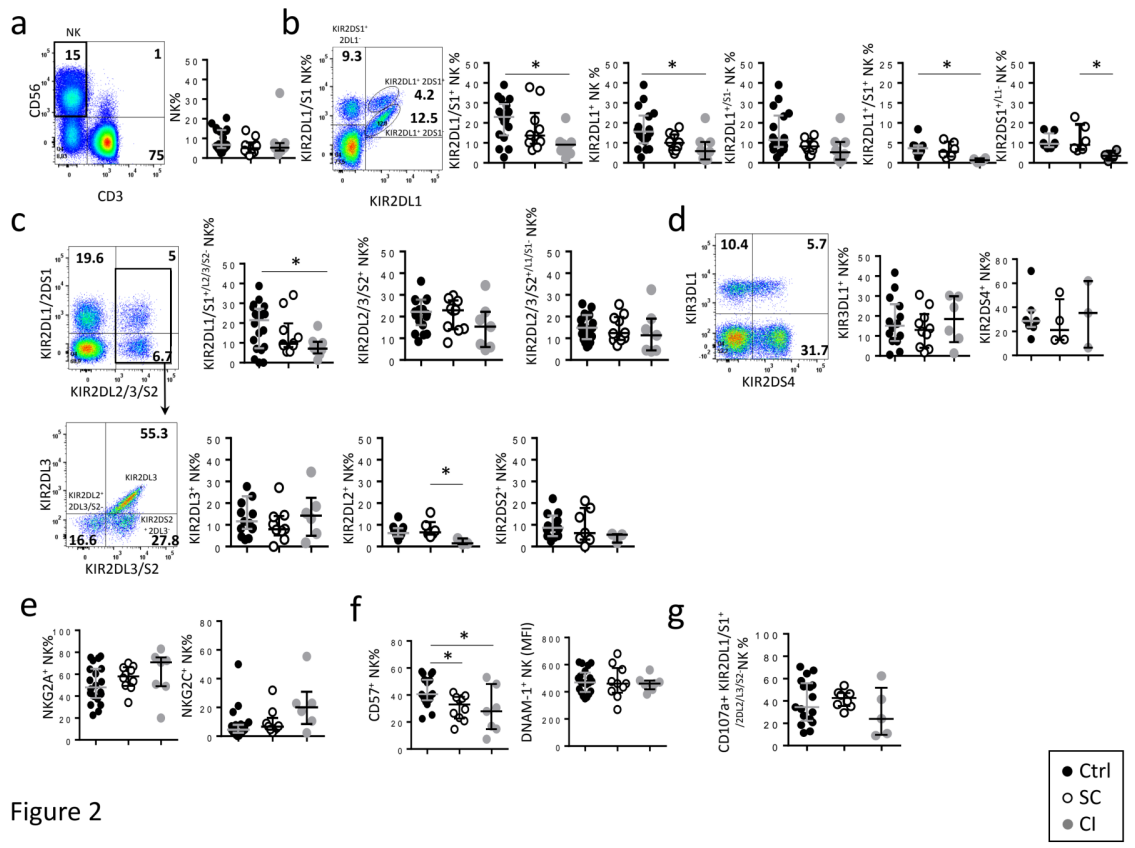

\section{Hosted file}

Fig 3 Legrand et al. 08.05.2020.pptx available at https://authorea.com/users/348965/articles/ 474135-influence-of-hla-c-environment-on-the-spontaneous-clearance-of-hepatitis-c-ineuropean-hiv-hcv-co-infected-individuals

\section{Hosted file}

Graphical abstract Legrand et al. 08.05.2020.pptx available at https://authorea.com/users/ 348965/articles/474135-influence-of-hla-c-environment-on-the-spontaneous-clearance-ofhepatitis-c-in-european-hiv-hcv-co-infected-individuals 